\title{
Bio-Inactive Somatotropin
}

National Cancer Institute

\section{Source}

National Cancer Institute. Bio-Inactive Somatotropin. NCI Thesaurus. Code C120371.

Bio-inactive somatotropin is encoded by mutated forms of the human GH1 gene. This protein lacks biological activity and is associated with a phenotype of functional growth hormone deficiency. 